\title{
Connected Science Learning: Linking In- School and Out-of-School STEM Educators Final Evaluation Report
}

\section{July 2017}

Submitted to:

National Science Teachers Association (NSTA) and Association of Science-Technology Centers (ASTC)

Prepared by:

Kelly Riedinger, Ph.D.

Senior Researcher

\author{
Oregon State University \\ Center for Research on Lifelong STEM Learning \\ 245 Gilbert Hall $\bullet$ Corvallis, Oregon \\ (541) 737-2197 • http://stem.oregonstate.edu/
}




\section{Table of Contents}

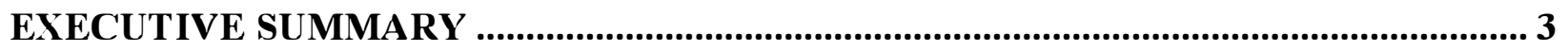

INTRODUCTION

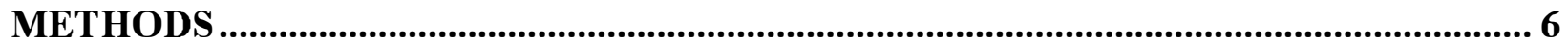

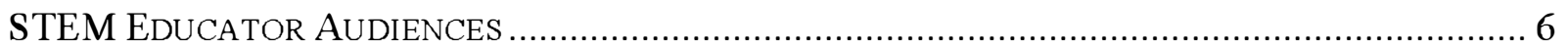

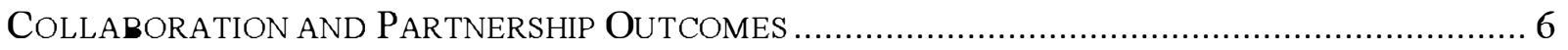

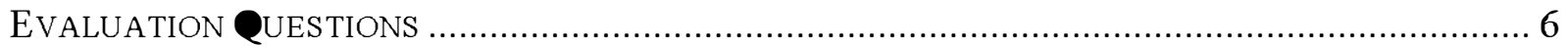

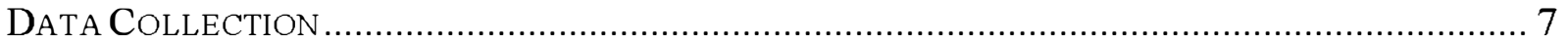

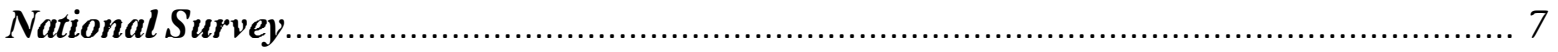

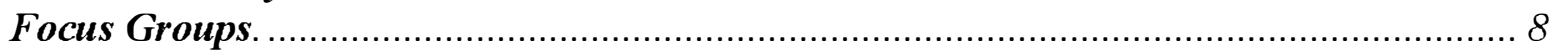

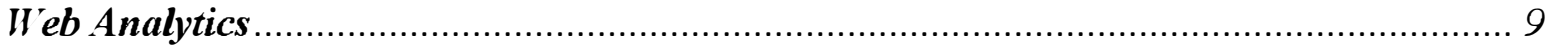

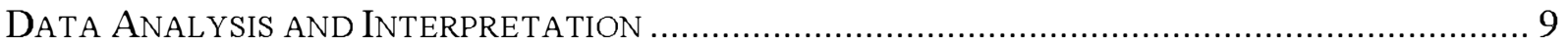

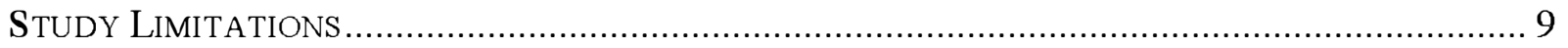

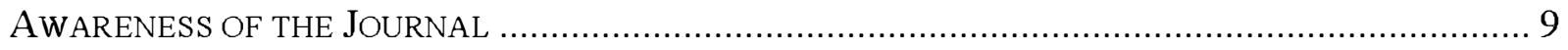

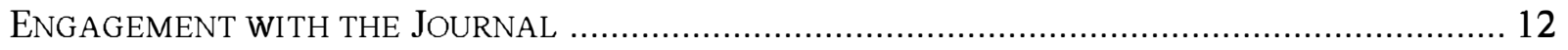

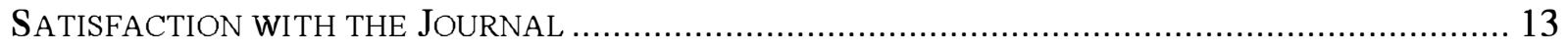

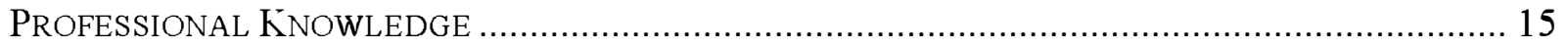

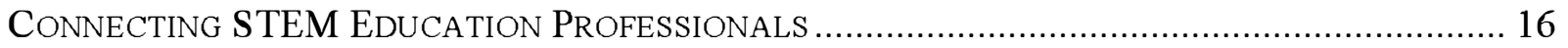

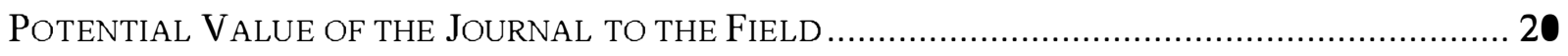

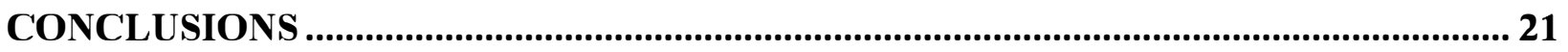

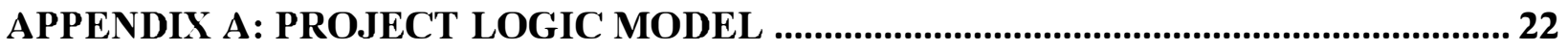

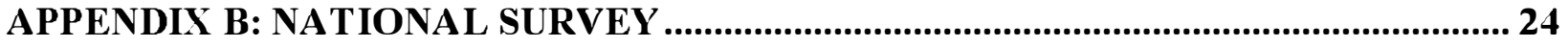

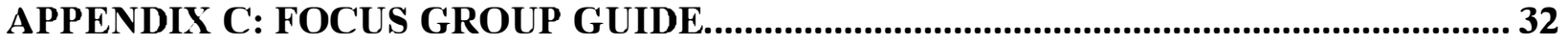




\section{Executive Summary}

This final evaluation report shares findings from the summative evaluation study of the Connected Science Learning: Linking In-School and U t-of-School STEM Learning (CSL) journal as well as themes that emerged across the broader three-year evaluation study. The ongoing study was conducted by researchers at the Center for Research on Lifelong STEM Learning at Oregon State University in collaboration with the National Science Teachers Association (NSTA) and the Association of Science-Technology Centers (ASTC).

The CSL journal was the result of an Early-concept Grant for Exploratory Research (EAGER) project funded by the National Science Foundation (NSF) (Award \#1420262) to develop, disseminate and evaluate a new resource for connecting STEM education practitioners across settings and to the teaching and learning knowledge base. The project was initiated by implementing a needs assessment and front-end evaluation to guide the development of the new resource. After identifying gaps where a new resource could contribute, the project team used key evaluation findings to inform the development of the pilot issues of the CSL journal. As the first pilot issue was launched, a formative evaluation study was implemented to gather feedback for improving future issues of the journal. The summative study reported here aimed to identify key outcomes of the grant-funded initiative on STEM education professionals who engaged with the journal as well as to understand any impacts on the broader field. Specifically, the study reported here focused on the following overarching summative evaluation question: Does the CSL journal add value to the field and target audience? Three additional sub-questions also guided the summative study:

1) Is the CSL journal successful in communicating current research to in-school and out-ofschool STEM education practitioners?;

2) Does CSL provide an effective mechanism for connecting educators across settings?;

3) To what extent, if at all, has the CSL journal catalyzed new (or expanded existing) partnerships or connections between in-school and out-of-school STEM education professionals and contexts?

To explore these evaluation questions, the study used a mixed-methods approach that incorporated the following complementary data collection strategies: focus groups, national survey, and review of web and social media analytics.

The following key findings emerged across the three-year evaluation study:

- A landscape analysis of existing resources in the STEM education field revealed, at the time of the front-end study, that there were limited resources designed specifically to connect educators across in-school and out-of-school settings;

- STEM education professionals were most interested in an online accessible journal and offered suggestions that aligned with their professional needs and interests for informing the development of the pilot issues of CSL;

- The formative evaluation study offered evidence to conclude that overall, STEM education professionals were satisfied with the pilot issue of CSL and outlined the potential value of the journal to the field, especially that it fills a current void by featuring projects and partnerships that span traditional education boundaries. Moreover, STEM 
education professionals noted that the CSL journal had high potential for creating connections and collaborative opportunities across settings;

- The summative study further elucidated the potential impacts of the journal and value to the field. As in the formative study, a notable value of the journal interpreted from the summative study findings was that it fills a niche in the field by featuring successful partnerships and models that create connections across the learning ecosystem. Additionally, STEM education professionals noted that the CSL journal translates research to practical applications, offers a mechanism for connecting STEM education practitioners, and provides an outlet where out-of-school education practitionerse can write about and share details of their work;

- There were also initial learning outcomes for STEM education professionals as a result of engaging with the journal including: becoming more familiar with research in the field, learning more about other education settings and how they contribute to the learning ecosystem, acquiring new resources for implementing STEM education, and learning about effective partnership models.

Overall, the three-year project has been successful in achieving project goals and objectives. The CSL journal has demonstrated value to the field as well as preliminary uptake among STEM education professionals. While there are still areas of opportunity for improving the journal, particularly related to continuing to advertise the journal and raise awareness, STEM education practitioners have been highly satisfied with CSL and see the value of the journal and related articles to their work.

\footnotetext{
${ }^{1}$ We note here that the CSL journal is not designed only for out-of-school educators to publish but rather this was the perception of the educators who participated in the evaluation study.
} 


\section{Introduction}

While there is a wealth of research-based knowledge in STEM education, there are limited resources for practitioners that are easily accessible and user-friendly that connect in-school and out-of-school education settings. With this need in mind, the National Science Teachers Association (NSTA), in collaboration with the Association of Science-Technology Centers (ASTC), applied for and was awarded a National Science Foundation (NSF) Early-concept Grant for Exploratory Research (EAGER). Through the initiative, the NSTA and ASTC would develop, disseminate and evaluate a new resource for STEM ${ }^{2}$ education practitioners in both inschool and out-of-school settings.

The project aimed to:

- Understand the landscape of resources currently available to STEM education practitioners in a variety of settings;

- Identify existing gaps in the current pool of resources available to STEM education practitioners;

- Pilot a resource that connects STEM education professionals across settings and to the growing research and knowledge base about STEM teaching and learning; and

- Conduct an ongoing, iterative evaluation study that informs the development of the new resource as well as the resulting outcomes and impact on the field.

Ultimately, the goal of the project was to develop a resource for STEM education professionals that features highly effective programs and shares research that connects preK-12 STEM learning in schools and out-of-school settings, specifically highlighting successful mechanisms for collaboration. A key component of the project was an ongoing evaluation study to assist the project leadership in making data-driven decisions. Throughout the grant-funded project, the evaluator - Riedinger, from the Center for Research on Lifelong STEM Learning at Oregon State University - was integrated in to the project team, participating in bi-weekly project meetings to share data and emerging findings from the ongoing evaluation study.

The first phase of the project involved assembling an advisory board of experts in the field as well as the implementation of a needs assessment and front-end evaluation study. The needs assessment and front-end study involved a landscape analysis of existing resources in the STEM education field and identifying gaps where a new resource could contribute. In addition, the front-end evaluation served as an opportunity to gather data regarding the target audience's interests and professional needs to drive the development of the resource. The needs assessment and front-end study offered evidence that a resource that connects researchers and practitioners across settings for learning was needed and that the target audience preferred an online accessible journal.

The project team used the data to guide the development of the first pilot issue of the Connected Science Learning: Linking In-School and Out-of-School STEM Learning (CSL) journal which launched in Spring 2016. In parallel, the project implemented a formative evaluation study designed to understand the target audience's perceptions and satisfaction with the first issue

\footnotetext{
${ }^{2}$ For the purposes of this study, we use the term STEM education professionals rather than science educator because our study participants included educators who taught a range of STEM content areas (e.g., mathematics educators, engineering educators). While there have been ongoing discussions in our field about what constitutes STEM, in this study we refer to a STEM educator as any professional engaged in one of the STEM content areas.
} 
while also collecting feedback to improve future issues. Overall, the formative study concluded that the journal was generally well-received and perceived by STEM education professionals as having value to the field. The formative study also provided data to inform changes and improvements to future issues.

In this final phase of the grant-funded project, two additional issues of CSL were launched on the journal website and the project team implemented a summative evaluation study to understand the outcomes for practitioners as well as broader impacts of the journal to the field. This report synthesizes the findings from the summative study, highlighting the outcomes of the grantfunded initiatives as well as the potential value of the journal on the broader STEM education field. As appropriate, we integrate findings from the front-end and formative study to articulate themes that emerged across the three-year evaluation study.

\section{Methods}

The overall project and study was framed by a logic model (Appendix A) that outlined the project inputs, activities and anticipated outcomes. The summative evaluation aimed to translate project goals into outcome measures that documented the quality of the final journal product, particularly in terms of impacts on the targeted audiences - including in-school and out-ofschool STEM education practitioners - as well as the strategic impacts that the journal has on the broader STEM education field.

\section{STEM Educator Audiences}

A main objective of the summative evaluation was to measure the degree to which STEM education professionals, in both in-school and out-of-school settings, engage with the CSL journal and related website. The summative evaluation study focused on the extent to which STEM education professionals find the journal and website appealing and applicable to their practice. Moreover, the study aimed to understand the extent to which the CSL journal influenced STEM educators' familiarity with learning ecosystem approaches, their knowledge of STEM learning across settings - especially in settings that are not their own - as well as their awareness and knowledge of research about STEM teaching and learning.

\section{Collaboration and Partnership Outcomes}

Another objective of the summative evaluation study was to gather evidence regarding the potential of the project and CSL journal for initiating dialogue between in-school and out-ofschool STEM practitioners and fostering collaborative partnerships across learning settings. The summative study sought to elucidate any conversations or considerations of new partnerships that may have been initiated as a result of the project as well as any interactions between STEM education professionals on the journal website, Twitter, and Facebook pages. As the journal is still relatively new, the summative study explored the extent to which any initial conversations emerged as well as the potential of the journal to facilitate future connections.

\section{Evaluation Questions}

The summative study was designed to specifically address the following overarching evaluation question: Does the CSL journal add value to the field and target audience? The summative evaluation study also focused on the following sub-questions:

4) Is the CSL journal successful in communicating current research to in-school and out-ofschool STEM education practitioners?; 
5) Does CSL provide an effective mechanism for connecting educators across settings?;

6) To what extent, if at all, has the CSL journal catalyzed new (or expanded existing) partnerships or connections between in-school and out-of-school STEM education professionals and contexts?

\section{Data Collection}

To gain insight in to these evaluation questions, we implemented the following data collection strategies:

National Survey. The predicted outcomes were primarily measured through a National survey administered through the Qualtrics online survey platform. The survey was developed in collaboration with the project leadership at NSTA and ASTC and iteratively reviewed by the team at the Center for Research on Lifelong STEM Learning. A copy of the survey can be located in Appendix B.

STEM education professionals registered on the CSL journal website were sent an email inviting them to participate in the survey and we also provided a link where visitors to the website could click to directly access the survey. An announcement regarding the evaluation study was sent out through both the NSTA and ASTC email newsletters with a direct link to the online survey and we posted on each organization's respective social media outlets (e.g., Twitter, Facebook). Finally, we sent announcements and the survey link through email lists of related partner organizations (e.g., NMEA scuttlebutt, NARST listserv).

There were 250 total responses to the survey who represented diversity across a number of variables such as: professional position, years of experience in the field, highest level of education, and engagement with professional STEM education organizations. The demographic details for the survey respondents are presented in Tables 1-4. As demonstrated in the tables, the survey sample was generally balanced across the demographic variables, with the exception of education level. Over $70 \%$ of respondents had an advanced degree, introducing a potential sample bias. The survey respondents also primarily engaged with NSTA and ASTC, which was expected given our recruitment strategies through NSTA and ASTC emails lists and social media outlets.

Table 1: Current Professional Position

\begin{tabular}{|c|c|c|c|}
\hline \multirow{2}{*}{$(\mathrm{n}=250)$} & $\begin{array}{c}\text { \# of } \\
\text { Responses }\end{array}$ & $\begin{array}{c}\text { \%o of } \\
\text { Responses }\end{array}$ \\
\hline \multirow{4}{*}{$\begin{array}{c}\text { Formal, School- } \\
\text { Based Education } \\
\text { Professionals }\end{array}$} & PreK-12 Classroom Teacher & $\mathrm{n}=45$ & $13.0 \%$ \\
\cline { 2 - 4 } & District Science Coordinator & $\mathrm{n}=6$ & $1.7 \%$ \\
\cline { 2 - 4 } & School or District Administrator & $\mathrm{n}=4$ & $1.2 \%$ \\
\cline { 2 - 4 } & School Assessment Specialist & $\mathrm{n}=2$ & $0.6 \%$ \\
\cline { 2 - 4 } & Instructional Coach or Professional Development Specialist & $\mathrm{n}=25$ & $7.2 \%$ \\
\hline \multirow{3}{*}{$\begin{array}{c}\text { Informal, Out-of- } \\
\text { School Education } \\
\text { Professionals }\end{array}$} & Curriculum Developer & $\mathrm{n}=27$ & $7.8 \%$ \\
\cline { 2 - 4 } & Educator at a Museum or Museum-like Setting & $\mathrm{n}=54$ & $15.6 \%$ \\
\cline { 2 - 4 } & Educator at a Zoo, Aquarium, Garden or Park & $\mathrm{n}=23$ & $6.7 \%$ \\
\hline \multirow{2}{*}{$\begin{array}{c}\text { College/University } \\
\text { Professionals }\end{array}$} & Community or Program Educator & $\mathrm{n}=31$ & $9.0 \%$ \\
\cline { 2 - 4 } & Member of the Media & $\mathrm{n}=1$ & $0.3 \%$ \\
\hline & College/University Faculty Member & $\mathrm{n}=24$ & $6.9 \%$ \\
\hline & College/University Staff & $\mathrm{n}=16$ & $4.6 \%$ \\
\hline
\end{tabular}




\begin{tabular}{|c|c|c|c|}
\hline Other Education & Business/Industry Professional in Education & $\mathrm{n}=5$ & $1.5 \%$ \\
\cline { 2 - 4 } Professionals & Independent Consultant or Evaluator/Researcher & $\mathrm{n}=21$ & $6.1 \%$ \\
\cline { 2 - 4 } & Scientist or Engineer & $\mathrm{n}=15$ & $4.4 \%$ \\
\hline
\end{tabular}

*Respondents could select more than one option.

\section{Table 2. Years of Experience as STEM Education Professional}

\begin{tabular}{|c|c|c|}
\hline$(\mathrm{n}=212)$ & $\begin{array}{c}\# \text { of } \\
\text { Responses }\end{array}$ & $\begin{array}{c}\text { \% of } \\
\text { Responses }\end{array}$ \\
\hline 0-2 Years of Experience & $\mathrm{n}=26$ & $12.3 \%$ \\
\hline 3-5 Years of Experience & $\mathrm{n}=32$ & $15.1 \%$ \\
\hline 6-10 Years of Experience & $\mathrm{n}=36$ & $17.0 \%$ \\
\hline 11-15 Years of Experience & $\mathrm{n}=30$ & $14.2 \%$ \\
\hline 16-20 Years of Experience & $\mathrm{n}=27$ & $12.7 \%$ \\
\hline More than 20 Years of Experience & $\mathrm{n}=61$ & $28.8 \%$ \\
\hline
\end{tabular}

Table 3. Highest Level of Education

\begin{tabular}{|c|c|c|}
\hline$(\mathrm{n}=212)$ & $\begin{array}{c}\# \text { of } \\
\text { Responses }\end{array}$ & $\begin{array}{c}\text { \% of } \\
\text { Responses }\end{array}$ \\
\hline High School Diploma or GED & $\mathrm{n}=2$ & $0.9 \%$ \\
\hline Associate's Degree & $\mathrm{n}=2$ & $0.9 \%$ \\
\hline Bachelor's Degree & $\mathrm{n}=58$ & $27.4 \%$ \\
\hline Master's Degree & $\mathrm{n}=107$ & $50.5 \%$ \\
\hline Doctorate Degree (PhD, EdD, JD, MD) & $\mathrm{n}=43$ & $20.3 \%$ \\
\hline
\end{tabular}

Table 4. Respondents' Primary Professional Organizations or Group

\begin{tabular}{|c|c|c|}
\hline$(n=201)$ & $\begin{array}{c}\text { \# of } \\
\text { Responses }\end{array}$ & $\begin{array}{c}\text { \% of } \\
\text { Responses } \\
\end{array}$ \\
\hline National Science Teachers Association (NSTA) & $\mathrm{n}=62$ & $30.9 \%$ \\
\hline Association of Science-Technology Centers (ASTC) & $\mathrm{n}=41$ & $20.4 \%$ \\
\hline Association for the Advancement of Science (AAAS) & $\mathrm{n}=10$ & $5.9 \%$ \\
\hline Association of Zoos and Aquariums (AZA) & $\mathrm{n}=8$ & $4.0 \%$ \\
\hline NARST & $\mathrm{n}=7$ & $3.5 \%$ \\
\hline North American Association for Environmental Education (NAAEE) & $\mathrm{n}=7$ & $3.5 \%$ \\
\hline Afterschool Alliance & $\mathrm{n}=6$ & $3.0 \%$ \\
\hline National Marine Educators Association (NMEA) & $\mathrm{n}=4$ & $2.0 \%$ \\
\hline American Education Research Association (AERA) & $\mathrm{n}=3$ & $1.5 \%$ \\
\hline Association for Science Teacher Education (ASTE) & $\mathrm{n}=3$ & $1.5 \%$ \\
\hline American Society for Engineering Education (ASEE) & $\mathrm{n}=3$ & $1.5 \%$ \\
\hline Citizen Science Association (CSA) & $\mathrm{n}=2$ & $1.0 \%$ \\
\hline National Association of Biology Teachers & $\mathrm{n}=2$ & $1.0 \%$ \\
\hline International Technology and Engineering Educators Association (ITEEA) & $\mathrm{n}=2$ & $1.0 \%$ \\
\hline Other & $\mathrm{n}=39$ & $19.4 \%$ \\
\hline
\end{tabular}

Focus Groups. We conducted a round of focus groups in conjunction with the NSTA regional conference in Portland, Oregon. Similar to the National survey, the focus group guide was developed with input from NSTA and ASTC and aligned with the study objectives and evaluation questions. The NSTA provided a full list of all participants registered for the conference and we used a random sampling process to invite conference attendees to participate in the focus groups. In total, 19 STEM education professionals participated in the focus groups including: 7 school-based educators, 2 college/university personnel, and 10 out-of-school 
educators. The focus groups lasted approximately an hour and a half and were audio recorded for analysis. A copy of the focus group guide can be found in Appendix C.

Web Analytics. The team also collaborated with NSTA to compile and interpret web analytic data from the CSL website using a data range from January 2017 to July 2017. These analytics provided us with initial data to start to understand awareness and engagement with the journal among the target audience. For instance, we are able to understand the extent to which marketing strategies increase the rate of new visitors to the site, where visitors are coming from, how long they engage with the site, and what pages they visit the most frequently. The analysis also included data from the CSL journal's Facebook page and Twitter handle such as number of likes, shares, comments on posts, and mentions by other organizations and educators. These data provided some insights in to STEM professionals' awareness and engagement with the journal while also highlighting early interactions between STEM education professionals through the journal's social media outlets.

\section{Data Analysis and Interpretation}

The quantitative data from the survey were analyzed using tools in Qualtrics to general descriptive and inferential statistics, as appropriate. For instance, we used the comparison tools to understand any differences between STEM education professionals based on variables such as learning setting and level of engagement with the journal. The qualitative data from the focus groups and open-ended survey items were analyzed within the rigors of qualitative research. The data were analyzed using an iterative coding process to identify emergent themes. We initially reviewed the data to generate an initial coding framework and then refined the codes as necessary by collapsing categories and elaborating on our descriptions. We applied the coding framework systematically while also checking the data to look for confirming and disconfirming evidence to support claims and assertions.

\section{Study Limitations}

Many of the findings reported here are synthesized from the data provided on the National survey and further corroborated by comments made during the focus groups. While there were 250 total responses to the National Survey, a majority of respondents $(n=130)$ were unfamiliar with the journal prior to receiving the survey announcement and therefore, the survey findings represent a smaller sample of respondents who previously engaged with the CSL journal. The study was not designed to produce generalizable results but the findings should be interpreted with caution. The study did, however, offer initial evidence that the CSL journal resulted in positive outcomes for STEM education professionals and has the potential for broader impacts on the field.

\section{Study Findings}

The key findings from the summative study are reported here, organized by each of the broad themes that emerged from the study and linked with previous findings from the front-end and formative studies where relevant.

\section{Awareness of the Journal}

A key task of the project was to develop awareness of the journal among STEM education professionals across a broad range of learning settings. At the time of the formative study, the national survey revealed that approximately a third (34.2\%) of survey respondents knew about 
the CSL journal before receiving the survey invitation and had heard about the journal in the following ways: NSTA e-newsletter (32.3\%), professional conferences (19.4\%), ASTC Informer email news bulletin (17.2\%), NSTA website (17.2\%), email listservs (16.1\%), or from a colleague $(15.1 \%)$.

On the summative survey, we included an equivalent question to understand current awareness of the CSL journal among STEM education professionals. Similar to the formative survey, a little more than a third of respondents $(37.0 \%, n=88)$ were familiar with CSL and about half of the respondents that were aware of the journal were also subscribers $(n=46)$. Survey respondents who had not yet subscribed $(n=20)$ indicated the following reasons:

- I was not aware that I could subscribe $(n=12)$;

- I do not know how or where to subscribe $(n=5)$;

- I do not want to receive journal updates in my email $(n=1)$

Survey respondents noted that they learned about the journal through the following strategies:

- NSTA e-newsletter $(\mathrm{n}=30)$;

- $\quad$ NSTA website $(\mathrm{n}=21)$;

- ASTC Informer email new bulletin $(\mathrm{n}=18)$;

- From a colleague $(\mathrm{n}=17)$;

- ASTC website $(n=12)$;

- ASTC Dimensions journal ( $\mathrm{n}=11)$;

- From CSL journal project team/staff $(n=9)$

- Professional conferences ( $n=9)$;

- Through participation in survey or focus group $(n=6)$;

- Online discussion forum or group $(n=6)$;

- NSTA journals $(n=5)$;

- Social media (Facebook, Twitter) $(n=5)$;

- From a CSL author/contributor $(n=3)$;

- Web search $(n=1)$;

- Email listserv (e.g., Scuttlebutt, NARST) (n=1); and

- $\quad$ NSTA Informal Science Education Committee $(n=1)$

The analytics from the CSL journal website provide data that further highlight trends in usage. As noted in Figures 1 and 2, peaks in usage align with several of the strategies identified by survey respondents. For instance, there are increases in users on the site that align with dates of professional conferences held over the spring (e.g., NSTA National Conference), email newsletters, and the release of new articles on the website. These data further corroborate that the current mechanisms for marketing the journal have demonstrated some initial success. Moreover, Figure 3 demonstrates the breakdown of new versus previous users to the site, suggesting that the strategies are also reaching new audiences and increasing awareness of the journal in the STEM education field. 
Figure 1. User Sessions by Month from January-July 2017

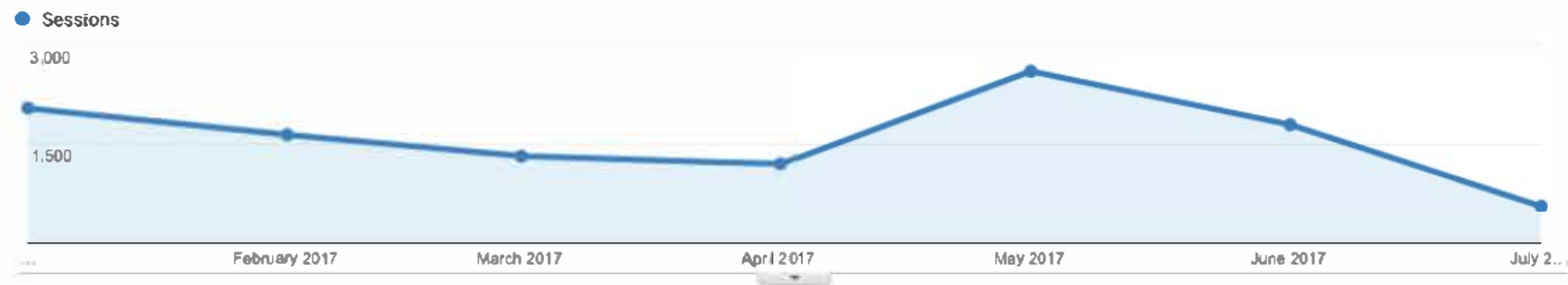

Figure 2. User Sessions by Day from January-July 2017

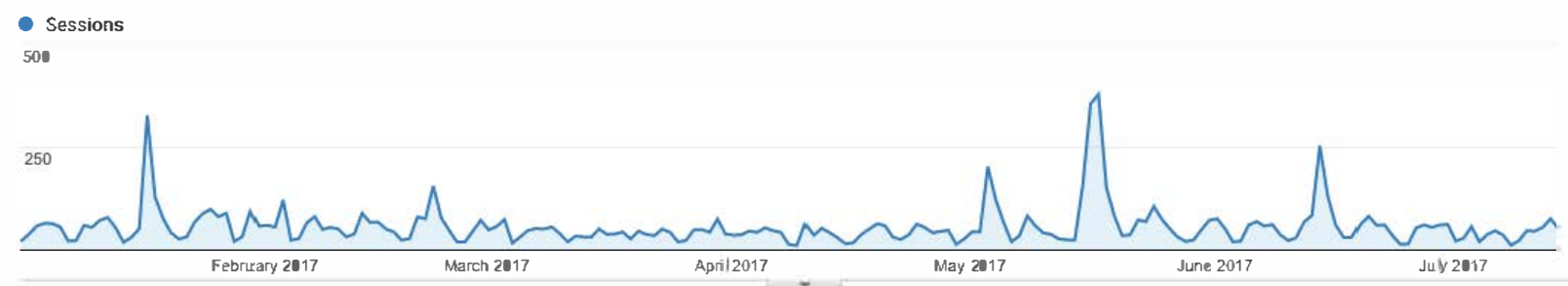

Figure 3. New vs. Returning Visitors

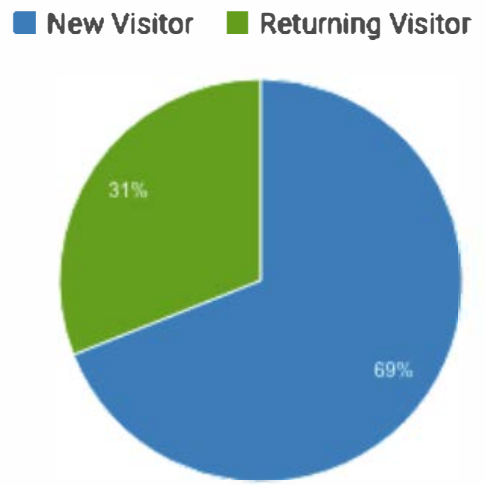

While there has been some preliminary success in raising awareness about the journal among STEM education professionals, the data also suggest that there is an opportunity to increase efforts and diversify strategies for reaching a broad audience of STEM educators. Almost two thirds (63\%) of the survey respondents had not previously heard of the joumal and comments made during the focus group discussion indicated that many of the participants had never heard about the CSL joumal or project.

Across the data collection stategies, the findings suggest that NST A and ASTC should continue implementing the strategies that have demonstrated success (e.g., e-newsletters/bulletins, professional conference, advertising in other NSTA/ASTC publications) while also identifying new strategies for marketing the joumal more broadly to STEM education practitioners and with a wider range of related organizations (e.g., Afterschool Alliance, North American Association for Environmental Education, National Alliance for Broader Impacts, AAAS). 


\section{Engagement with the Journal}

The summative study also sought to examine STEM education professionals' level of engagement with the CSL journal. This was evaluated through questions on the summative survey and discussed during the focus groups. The focus group included a question that specifically asked participants to describe how they had engaged with the CSL journal and the survey included a parallel question. Further, the web analytic data helped in understanding how visitors use the CSL journal website.

Figure 4 displays findings from this survey item. The respondents had varied levels of engagement, but a majority had at least read through some of the articles from the first and second issue. The participants in the focus group, however, differed in their engagement with the journal. Most had either never heard of the journal prior to receiving the invitation to participate in the discussion or had heard of the project but had not yet visited the website or read an article. This discrepancy is likely due to how we recruited participants for each data collection strategy. Participants in the focus group were drawn from registered NSTA conference participants while the survey largely was completed by journal subscribers. Therefore, it is not surprising that there was more engagement with the journal among survey responders as compared to the focus group participants. Furthermore, the survey represented a larger sample of STEM education professionals which also could account for differences in engagement.

\section{Figure 4. Engagement with the Journal}

To date, how would you describe your engagement with the Connected Science Learning journal? (Please select all that apply.) $(n=134)$

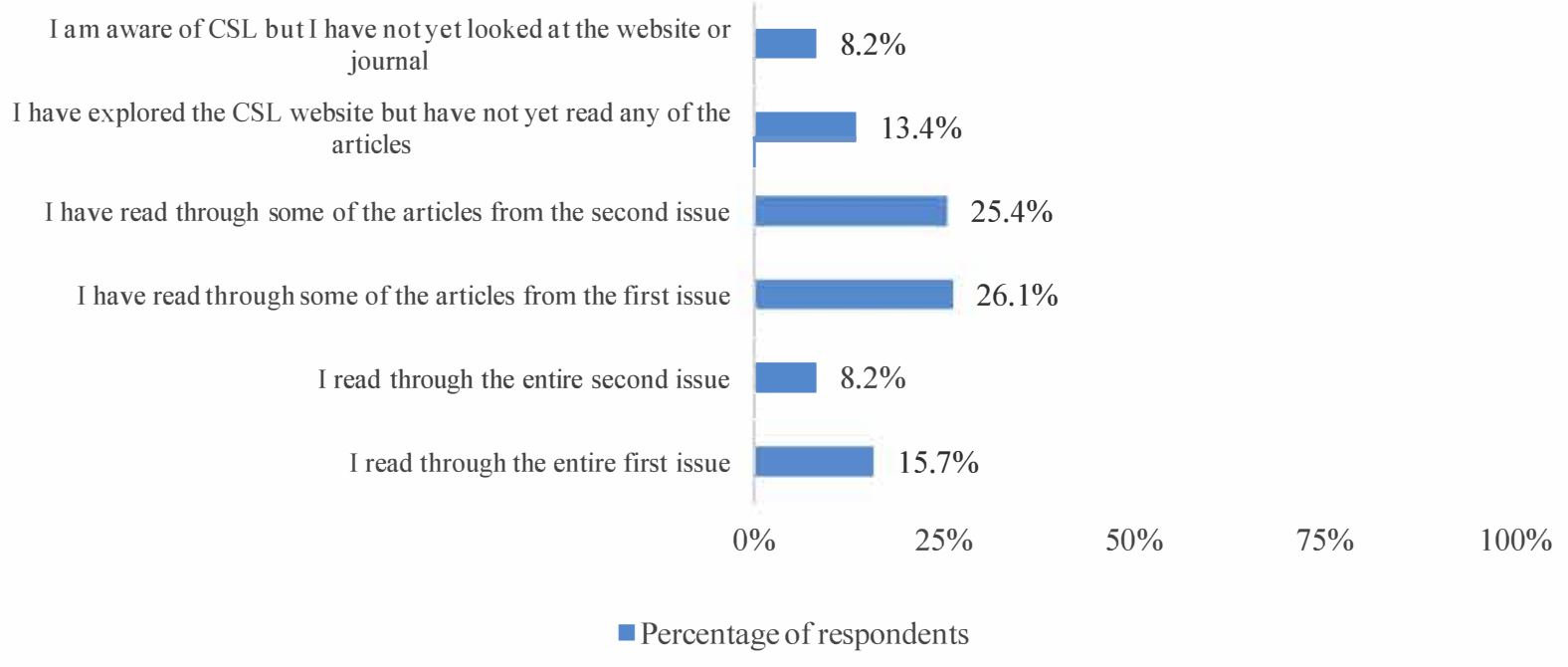

A second question on the survey prompted respondents to indicate how often they engaged with the journal. Most of the respondents indicated that they visited the website rarely (about one a month) or occasionally (a few times a year) (Figure 5). Engagement might change as the website populates further but this finding also suggests that NSTA and ASTC might consider new features on the website that entice STEM education professionals to visit more frequently. 
Figure 5. Frequency of Visiting CSL Journal

How often do you visit the Connected Science Learning journal website? $(\mathrm{n}=85)$

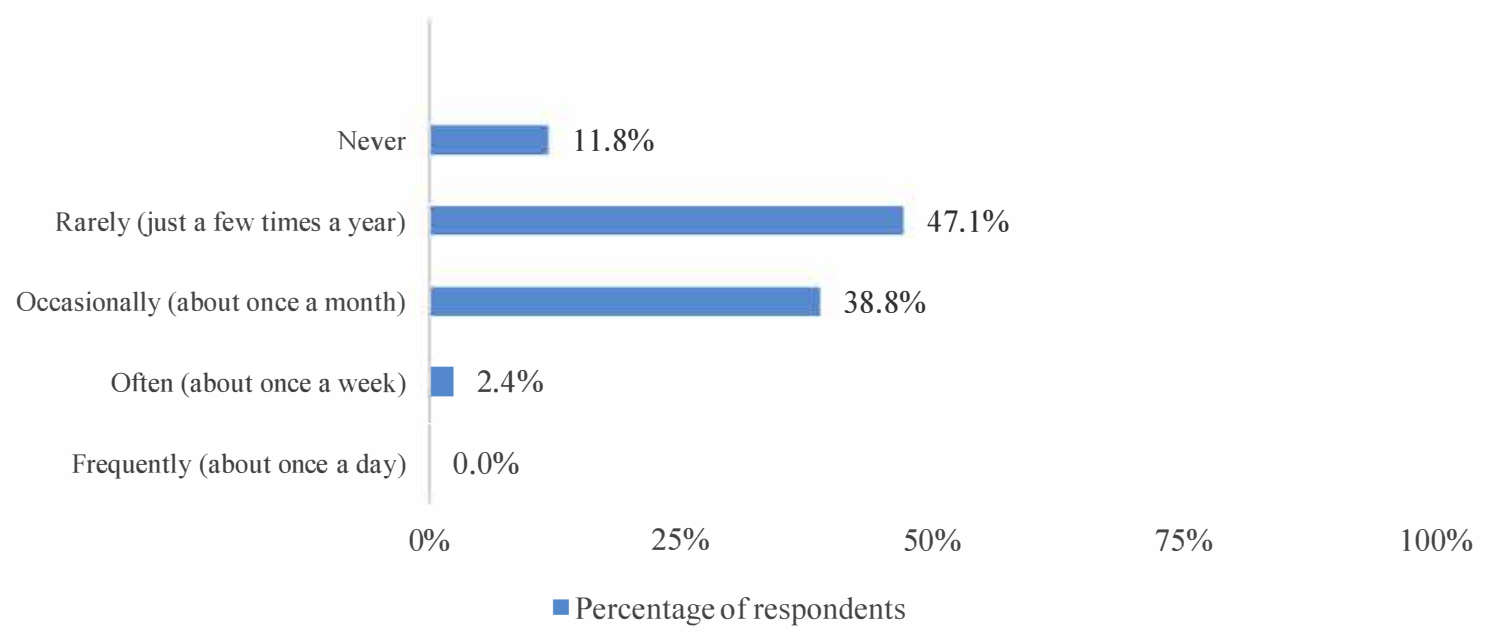

The web analytic data also helped to illuminate how STEM education professionals were engaging with the CSL website. The session duration of visitors to the website home page is approximately 1 minute and 59 seconds and there have been roughly 11,000 sessions over the time frame examined. Table 5 displays how visitors are using the CSL website, including the top ten visited articles. As visitors explore each article, they spend approximately two to four minutes on each article page.

Table 5. Most Visited Pages on CSL Website

\begin{tabular}{|l|c|c|}
\hline Page Title & $\begin{array}{c}\text { Page } \\
\text { Views }\end{array}$ & $\begin{array}{c}\text { Average } \\
\text { Time on } \\
\text { Page }\end{array}$ \\
\hline 1. Science Club & 990 & $3: 39$ \\
\hline 2. Collaborationet Good Coffeee Connected Science Learning Success & 771 & $4: 02$ \\
\hline 3. SciGirl Strategies & 678 & $3: 29$ \\
\hline 4. Research to Practice, Practice to Research & 638 & $3: 35$ \\
\hline 5. Modeling Collaboration for Learning & 583 & $3: 02$ \\
\hline 6. STEM Learning Across Boundaries & 553 & $2: 31$ \\
\hline 7. STEM Learning Ecologies & 550 & $3: 38$ \\
\hline 8. Seeding the Future & 543 & $3: 51$ \\
\hline 9. STEM Pathways & 336 & $2: 34$ \\
\hline 10. The Healthy Flea Market & 334 & $2: 10$ \\
\hline
\end{tabular}

\section{Satisfaction with the Journal}

Although the formative study provided preliminary overall ratings of the CSL journal and ways to improve the resource, we included a set of questions on the summative survey to ensure that STEM education professionals were still satisfied with the journal after the iterative improvements to the website. On both the formative and summative surveys, there were a series of net promoter like questions that prompted respondents to indicate a rating on a scale from 1 to 
10 regarding the CSL journal and related website. The results of these questions are presented in this section:

- Overall, how satisfied are you with the Connected Science Learning journal? Mean score $=7.2(\mathrm{n}=70)$;

- How likely are you to continue following the Connected Science Learning journal as new articles and issues are released? Mean score $=7.8(\mathrm{n}=76)$;

- How likely are you to recommend the Connected Science Learning journal to a colleague? Mean score $=7.5(n=72)$;

Across these three questions, the average score was 7.5 on a scale from 1 to 10 suggesting that survey respondents were generally satisfied, likely to follow the journal, and likely to recommend the resource to a colleague.

When prompted to elaborate on their ratings, there were a few patterns that emerged throughout the responses. Survey respondents indicated they provided high ratings primarily because they saw the value of the CSL journal:

"This is an important and valuable resource for in and out of school educators. It is beneficial to share what each is doing and how we can complement each other's efforts."

"CSL covers an important area not covered in other publications."

"I think it is an important are of work and research."

"I see this as a super valuable publication."

"I'm thrilled that this journal exists. It is of great benefit to manyl"

Another pattern noted among respondents, particularly related to why they provided ratings lower than 10, was due to a lack of clarity regarding the scope and identity of the journal. This was also echoed in the focus group discussions. Specifically, participants expressed concern about trying to be too many things to too many different stakeholder groups while not clearly defining the journals' identity or bounding the target audience.

I really want to like this journal. I hope that now that it is going strong, the editorial staff really think about: Is it a magazine or journal? Who is the audience? Can there be articles [in the journal] just on informal learning without being in service or in partnership to formal? "

"I have no idea what this [journal] is about."

"By trying to accommodate all stakeholders it seems to not fill a particular, unique niche."

"Connected Science Learning is pretty vague to me. Hard to know what you'll get from the articles."

"I hope that Connected Science Learning comes into its own and really begins to focus on its unique contributions. Right now, it seems like most of these articles could also be published in the other NSTA magazines. What is unique here -- the focus on informal is too weak, given the solid school focus on the other NSTA publications."

And, finally, a few respondents noted that the reason they provided ratings lower than 10 was simply because they had limited awareness and engagement with the CSL journal or because the journal was too new to adequately provide a rating. These comments included: 
"Have not used it enough to make a true informed opinion."

"Too soon to have a concrete opinion, but I am interested in following the CSL as new articles are released."

"Have not yet utilized the journal, but look forward to reading it."

"Not sure since I haven\& read much yet.e"

These comments reinforce the need for raising awareness and engagement with the CSL journal. Nonetheless, the overall findings from the formative questions on the survey and in the focus group discussions offer evidence to conclude that the journal has been well-received by STEM education professionals and they are generally satisfied with the resource.

\section{Professional Knowledge}

Another predicted outcome was that STEM education professionals would gain professional knowledge as a result of engaging with the journal and reading articles that featured successful partnership models. The focus group discussions provided preliminary evidence that the CSL journal influenced STEM education practitioners' professional knowledge. The ideas that surfaced during the focus groups were used to inform the development of a survey item that specifically asked respondents to identify what they learned as a result of engaging with CSL. The results of this survey item are presented in Table 6.

When asked to rate their level of agreement with each statement using a 5-point Likert scale from strongly disagree to strongly agree, the scores varied from 3.7 to 4.0 for each item, suggesting that respondents generally agreed that the CSL journal led to positive outcomes such as learning about: research in the field, other settings for STEM learning, effective partnership models, and new resources for enhancing their practice.

\section{Table 6. Learning Outcomes for STEM Education Professionals}

\begin{tabular}{|l|c|}
\hline & Mean Score \\
\hline $\begin{array}{l}\text { As a result of Connected Science Learning, I learned about } \\
\text { research in the STEM education field }\end{array}$ & 3.8 \\
\hline $\begin{array}{l}\text { As a result of Connected Science Learning, I learned more about } \\
\text { other settings for STEM learning }\end{array}$ & 3.8 \\
\hline $\begin{array}{l}\text { As a result of Connected Science Learning, I learned about } \\
\text { effective partnership models }\end{array}$ & 4.0 \\
\hline $\begin{array}{l}\text { As a result of Connected Science Learning, I have new } \\
\text { resource(s) that enhance my work in STEM education }\end{array}$ & 3.7 \\
\hline
\end{tabular}

Additional comments in the elaboration section of the question further highlighted these trends:

"There are some significant efforts going on in this country that I would NEVER have known about.e'

"I am always exploring options for new STEM programming ideas and ways to partner on various projects. No need to reinvent the wheel when there are already so many great programs that have been tested and implemented."

"I think it helps just to see what people are doing and then reaching out to people who have similar interests."

"Another resource to get ideas and knowledge." 
"The journal provides insight as to how collaborations between formal and nonformal educators can occur."

"Provides tangible examples of how informal and formal science educators can partner to achieve science learning goals."

A follow-up, open-ended question asked survey respondents to identify how they would use what they have learned as a result of the CSL journal. Most of the comments that were provided explained that they would use the information to share with colleagues or to initiate a conversation. The following quotes exemplify these ideas:

"I continue to share with our Education Department and Senior Staff for their interest and follow up."

"I want to have a discussion with colleagues about an article after we've all read it-when it applies to something we do or are planning."

"[I use the journal] to keep abreast of the field, share with junior staff as part of professional development, use as a starting point for deeper dives into interesting areas/topics."

"I currently meet with nonformal educators in my state to discuss the needs of teachers. The information and ideas learned from the journal will help spur more in-depth conversations with formal and nonformal educators."

"I share with my staff."

"[I] share with my networks and collengues."

"I plan to share it with colleagues I work with to discuss."

Collectively, the survey items and additional comments emphasize the areas where STEM education professionals might benefit from engagement with the journal. Notably, survey respondents considered the journal as a way to learn about the work of others as a source of ideas and inspiration. Overwhelmingly, the survey respondents intended to share the articles with colleagues and to use them as a means to engage in conversations for thinking about programs and creating connections across the learning ecosystem.

\section{Connecting STEM Education Professionals}

A key objective of the CSL resource was to serve as a mechanism for connecting STEM education practitioners across settings. To measure how the CSL journal has fostered such connections, we asked a question on the summative survey, informed by comments made during the focus groups.

Figure 6 presents the findings from this survey item. A little more than a third of participants have not yet made connections with other STEM education professionals as a result of CSL. It is promising, however, that a majority of STEM education professionals (58.9\%) have already made some kind of connection as a result of the CSL project. It was most common for survey respondents to connect with other practitioners by sharing a CSL article (35.3\%). We assume that additional connections will be made as the journal becomes more well-known and established. 


\section{Figure 6. Connections between STEM Education Professionals}

\section{In what ways have you connected with other STEM education professionals as a result of the CSL journal? (Please select all that apply.) $(n=85)$}

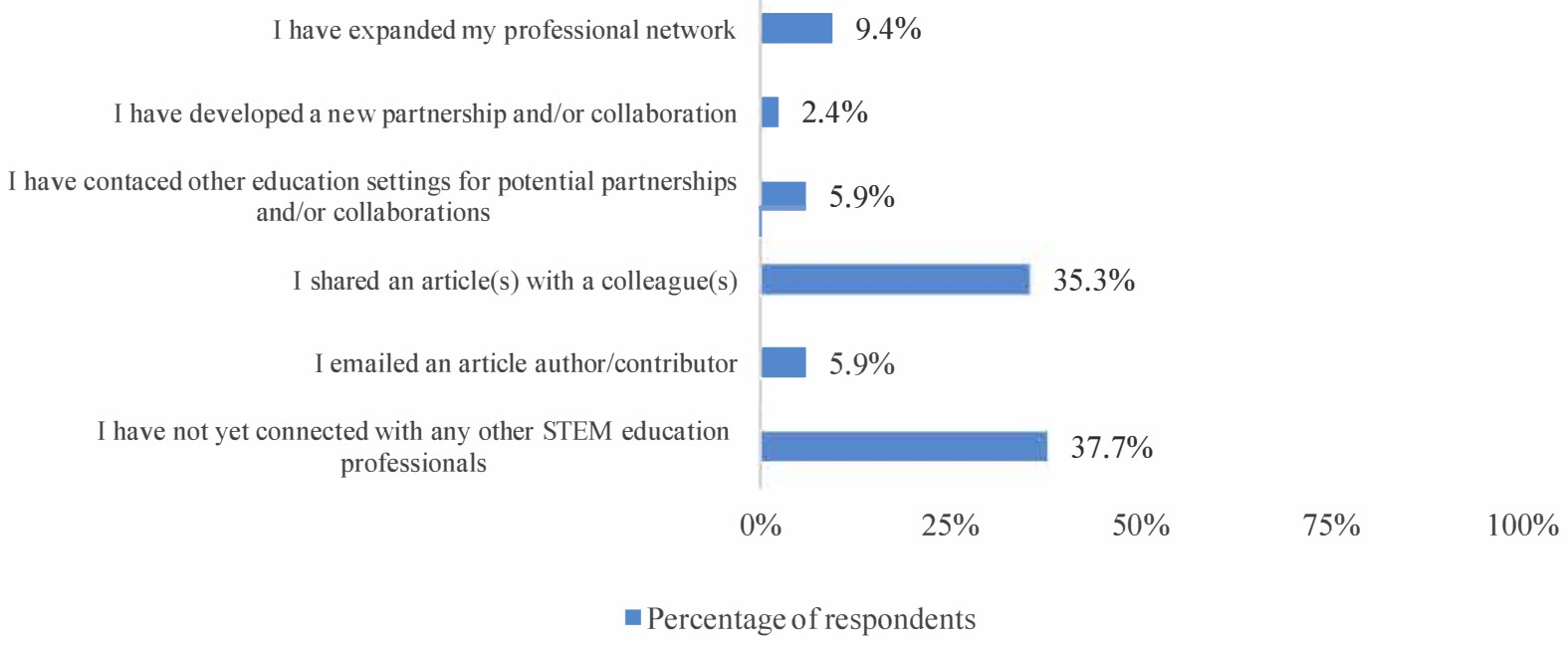

Another strategy we used to understand connections between STEM education professionals was by reviewing the comment section of each article on the CSL journal website. On issue one, there were a total of ten comments made by readers, but only one author response. In issue two, there were two comments and there has been one comment so far in issue three. Participants in both the formative and summative focus groups noted that the comment section might require an NSTA staff member to monitor the discussions as well as a mechanism for alerting authors when a comment is made about their article.

We also examined the CSL Facebook page and Twitter account to understand other ways that STEM education professionals might be connecting through the journal's social media outlets. At the time of this report, the CSL Facebook page had 168 likes and 174 followers. Visitors to the CSL Facebook page engaged with some of the posts: several of the posts received one to four likes from followers or visitors and two of the posts received comments. Since the Facebook page was established in September 2016, there have been 74 total shares of the posts made. While a majority of the shares were by ASTC or other NSTA journals, the posts have also been shared by the following organizations:

- ENet Learning

- Colorado Science and Engineering Fair

- Oregon Coast STEM Hub

- Discovery Science Center

- Oregon Sea Grant

- Aquatic Animal Health Program

- Central Oregon STEM Hub

- Education Library at Western University's Faculty of Education

- The STEM Guides Project - Central Lincoln County Hub 
- Center for Science and Schools

- The Mr. Science Show

Figure 7 shares the CSL post regarding a US News article about After-school programs that was the most often shared post by followers and related organizations.

\section{Figure 7. Most Commonly Shared Post on CSL Facebook Page}

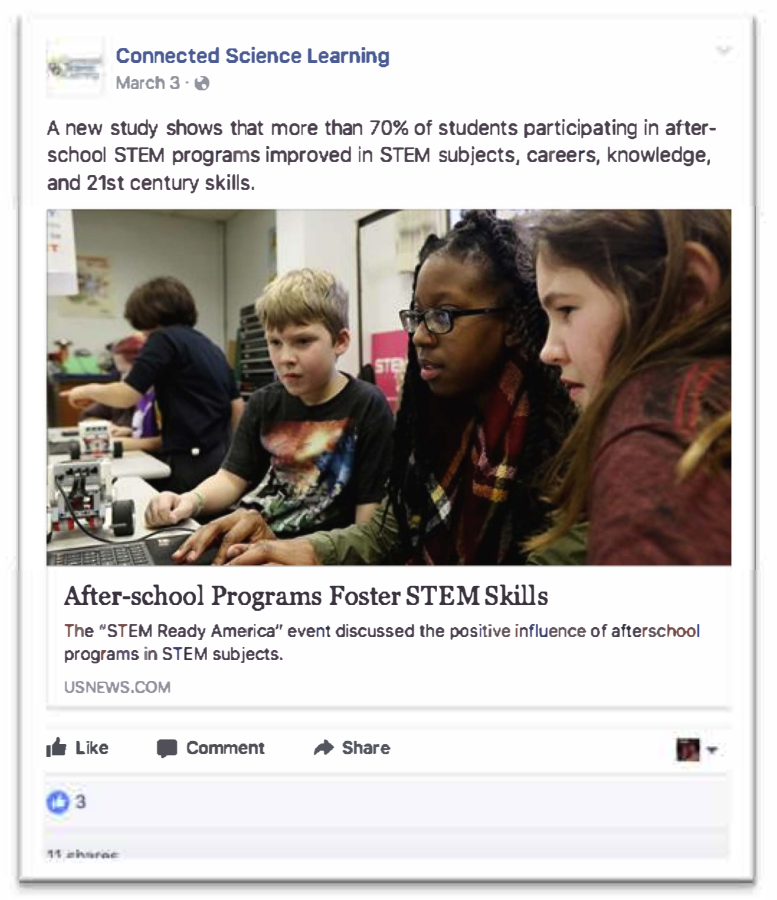

Finally, CSL was mentioned once in a post made by a page follower, the N.C. Office of Environmental Education and Public Affairs (Figure 8).

\section{Figure 8. CSL Mentions on Facebook}

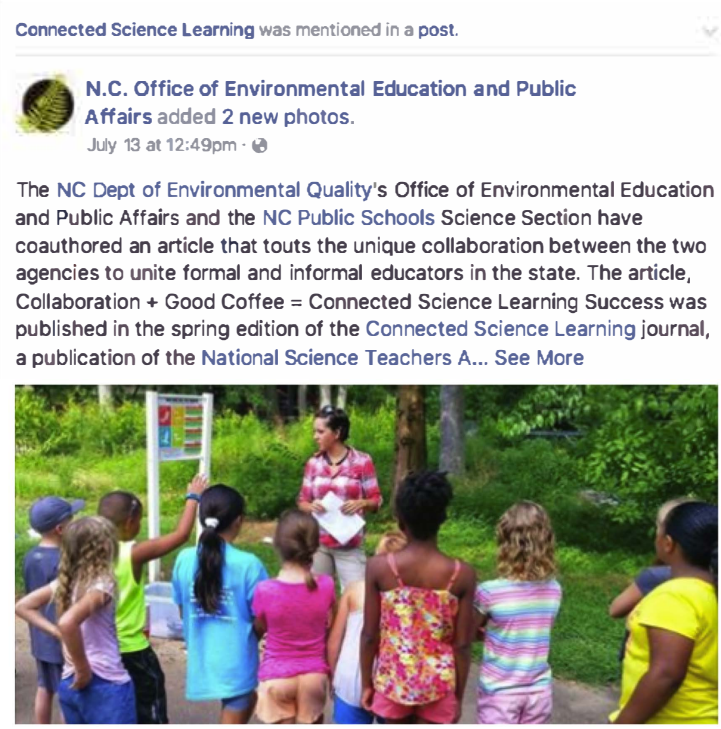


The data we gathered from the CSL Facebook page suggested that at the time of the summative study, there were a few preliminary connections, particularly with related STEM organizations (e.g., Oregon Coast STEM hub, Colorado Science and Engineering Fair, N.C. Environmental Education and Public Affairs).

A review of the Twitter analytic data similarly revealed that the @CSLjournal account has fostered a few initial connections with related STEM organizations. At the time of the summative study, there were 104 followers of $@$ CSLjournal and 166 tweets. Table 7 depicts analytic data from the @CSLjournal Twitter account, including new followers, profile visits, tweets, tweet impressions, and mentions by month over the study period. Tweet impression refers to tweets that generate interactions or replies from other Twitter users.

Table 7.@CSLjournal Twitter Analytic Data by Month

\begin{tabular}{|c|c|c|c|c|c|}
\hline & $\begin{array}{c}\text { New } \\
\text { Followers }\end{array}$ & $\begin{array}{c}\text { Profile } \\
\text { Visits }\end{array}$ & Tweets & $\begin{array}{c}\text { Tweet } \\
\text { Impressions }\end{array}$ & Mentions \\
\hline July 2017 & 1 & 10 & 7 & 1847 & 0 \\
\hline June 2017 & 5 & 16 & 20 & 2619 & 6 \\
\hline May 2017 & 11 & 44 & 21 & 8007 & 13 \\
\hline April 2017 & 8 & 33 & 19 & 2305 & 4 \\
\hline March 2017 & 8 & 35 & 21 & 8783 & 4 \\
\hline February 2017 & 9 & 35 & 16 & 1984 & 3 \\
\hline January 2017 & 11 & 21 & 10 & 5914 & 3 \\
\hline
\end{tabular}

As listed in Table 7, @CSLjournal has received 33 mentions over the timeframe examined (January - July 2017) by organizations and users such as ASTC, CSL article authors/contributors, and STEM education organizations (e.g., @NorthCarolinaEE, @STELAR_CTR, @ALSciTeachers).

Figure 9. Sample@CSLjournal Twitter Mention

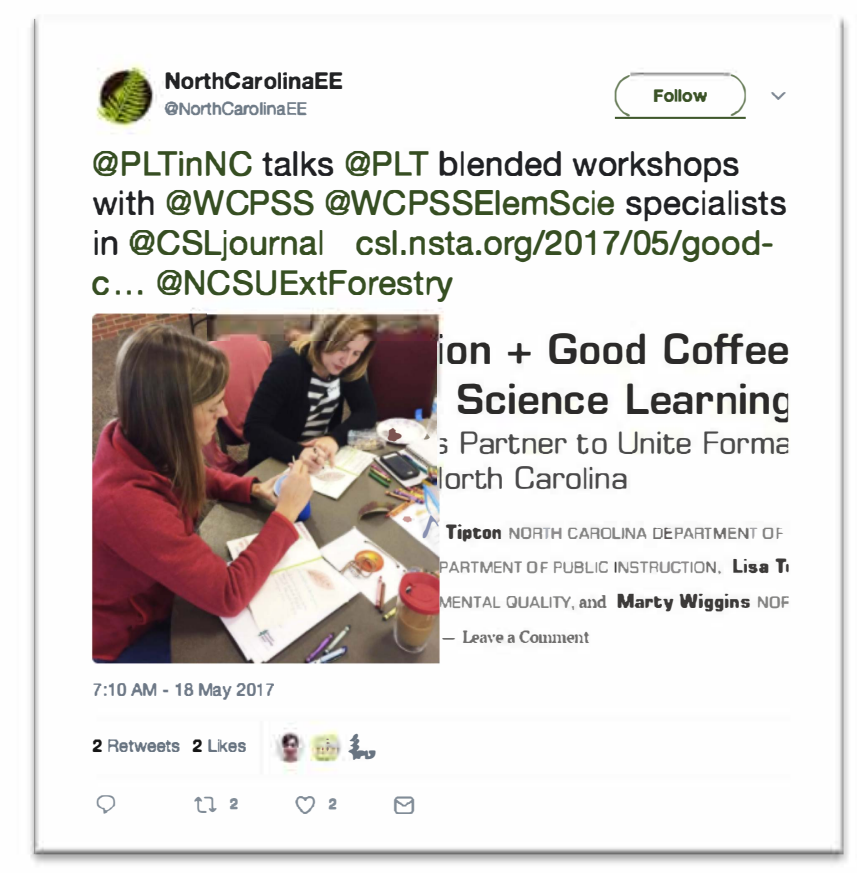


The Twitter analytic data also demonstrated how Twitter users engaged with tweets and mentions by other users. The "engagement" metric from the Twitter analytic data measures how much users interact with a tweet through actions such as (but not limited to): clicks, retweets, replies, follows, likes, and hashtags. The engagement data suggests that users are interacting with (a)CSLjournal tweets, as presented in Table 8. The tweets with the highest level of engagement are included in Figure 10.

Table 8. Tweet Engagement Data by Month

\begin{tabular}{|l|c|}
\hline & $\begin{array}{c}\text { Average Engagement } \\
\text { for Tweets }\end{array}$ \\
\hline July 2017 & 3.4 \\
\hline June 2017 & 1.7 \\
\hline May 2017 & 3.5 \\
\hline April 2017 & 3.5 \\
\hline March 2017 & 6.0 \\
\hline February 2017 & 2.3 \\
\hline January 2017 & 3.1 \\
\hline
\end{tabular}

\section{Figure 10. Top Tweets by Engagement Data}

March: 23 Total Engagements

CSL Editor @CSLjournal

CYMI, find out what happened last week in terms of science education news:

http://nstacommunities.org/blog/2017/03/03/ed-news-idaho-

legislature-approves-new-science-standards-that-omit-climatechange/ ... \#NSTA
April: 25 Total Engagements

CSL Editor @CSLjournal

Read about a well-developed model for implementing the Engineering is Elementary curriculum:

http://csl.nsta.org/2017/01/modeling-collaboration-for-

learning/ ...
May: 40 Total Engagements

CSL Editor बCSLjournal

The third issue of Connected Science Learning is live! Dennis

Schatz, editor of CSL, introduces the issue here:

http://csl.nsta.org/2017/05/welcome-third-issue/

Collectively, the survey findings and analytic data suggest that there are some initial connections happening as a result of the CSL journal and related social media outlets, primarily between STEM education related organizations. We assume that these organizations act as a broker for connecting STEM education professionals by helping to share content from the CSL journal. While these connections are still limited, they point to the potential of the journal as a mechanism for facilitating interactions between STEM education professionals and relevant organizations.

\section{Potential Value of the Journal to the Field}

A question on the formative study and in the focus groups asked participants to indicate the potential value of the CSL journal to the field. These responses were analyzed and the following themes emerged:

- The journal offers practice applications of STEM education research;

- The journal fills a current gap in the field by featuring successful partnership between inschool and out-of-school settings;

- The journal serves as a mechanism for connecting STEM education professionals across settings; 
- The journal provides out-of-school education practitioners a space to write about and share their work.

These ideas that emerged from the formative study were used to inform the development of an item on the summative survey regarding the value of the journal. Specifically, we used these themes as a way to learn more about what STEM education professionals saw as the most important contribution of the CSL journal to the field as well as to prompt their thinking for identifying any other ways the journal could add value to the field. The findings from this survey item are displayed in Table 9.

\section{Table 9. The Value of CSL to the STEM Education Field}

\begin{tabular}{|l|c|c|}
\hline$(\mathrm{n}=66)$ & \# of Responses & \% of Responses \\
\hline $\begin{array}{l}\text { The journal offers practical applications of STEM education } \\
\text { research }\end{array}$ & $\mathrm{n}=5$ & $7.6 \%$ \\
\hline $\begin{array}{l}\text { The journal fills a current gap in the field by featuring } \\
\text { successful partnerships between in-school and out-of--school } \\
\text { settings }\end{array}$ & $\mathrm{n}=31$ & $47.0 \%$ \\
\hline $\begin{array}{l}\text { The journal serves as a mechanism for connecting STEM } \\
\text { education professionals across settings }\end{array}$ & $\mathrm{n}=13$ & $19.7 \%$ \\
\hline $\begin{array}{l}\text { The journal provides out-of-school education practitioners a } \\
\text { space to write about and share their work }\end{array}$ & $\mathrm{n}=17$ & $25.8 \%$ \\
\hline
\end{tabular}

Overall, "The journal fills a current gap in the field by featuring successful partnerships between in-school and out-of-school settings" was ranked as the most important contribution of the journal to the field which further corroborates the findings from the formative study.

In addition, survey respondents noted a new potential area of impact, explaining that the CSL could foster new areas of inquiry. For instance, the CSL journal could catalyze research around measuring the impact of such partnerships and identifying elements of effective partnerships. The following quotes from the survey illustrate this idea:

"Provides some measure of the impact such partnerships can have, potentially opens up opportunities for further research? There's very little available on long term, in-depth STEM partnerships in the academic literature!"

"I think it is also a vehicle to have up and coming scholars publish. Also, it feels accessible on the web and can be a vehicle for building collaborations with young people to write."

\section{Conclusions}

The overarching evaluation question that drove this study was: Does the CSL journal add value to the field and target audience? Three sub-questions also drove the evaluation study and are addressed in this section. As noted earlier, these findings are largely based on the survey and focus group respondents which represents the perspectives of approximately 250 STEM education professions. These conclusions should be interpreted with this sample in mind.

Collectively, the findings from the ongoing, three-year evaluation study support the conclusion that the CSL journal adds value to the STEM education field and will continue to have an impact as it becomes more well-known and established. In particular, the CSL journal was perceived as valuable because it fills a niche in the field by publishing unique content around bridging in- 
school and out-of-school STEM learning. The CSL journal also adds value by translating research to practice for STEM educators across settings by sharing examples of evidence-based practices and programs. The participants in the evaluation study - especially those who identified as informal/out-of-school educators - also viewed the journal as a new outlet for sharing their work. There is initial evidence that the CSL journal can foster connections between STEM education organizations and practitioners. And, finally, there were also initial learning outcomes for STEM education prof essionals as a result of engaging with the journal including: becoming more familiar with research in the field, learning about other education settings, acquiring new resources for implementing STEM education, and learning about effective partnership models.

Is the CSL journal successful in communicating current research to in-school and out-of-school STEM education practitioners?

As related to this evaluation question, STEM education practitioners who participated in the evaluation study noted that they learned of research in the field and that the journal was successful in presenting the research in a way that was digestible and easy to understand. Moreover, the articles translated research to practice by offering examples of evidence-based practice that readers could implement in their own settings.

Does CSL provide an effective mechanism for connecting educators across settings?

There was preliminary evidence that educators across settings have made a few connections as a result of the CSL journal and related social media outlets. However, this evidence is limited and there is an opportunity for NSTA and ASTC to make a more concerted effort around offering specific mechanisms for facilitating these connections. Additional connections might also develop as more STEM education professionals learn of the CSL journal.

To what extent, if at all, has the CSL journal catalyzed new (or expanded existing) partnerships or connections between in-school and out-of-school STEM education professionals and contexts?

At the time of the summative study, two survey respondents did select "I have developed a new partnership and/or collaboration" but did not elaborate on their selections when prompted.

Therefore, the data collection efforts did not elucidate any specific new partnerships as a result of the CSL initiative but there is evidence to suggest it may have catalyzed at least a few connections. Further, an item on the National survey suggested that as a result of the project, respondents, to some extent, expanded their professional networks, contacted other education settings for potential partnerships, and emailed article authors/contributors. 


\section{Appendix A: Project Logic Model}

The logic model for the project outlines the specific inputs, activities and outputs for the project and identifies the predicted outcomes for the various targeted audiences. The logic model visually depicts the project activities, theory of action, and key indicators of success that will be used to measure the impact of the project. The logic model will guide the summative evaluation study.

\section{NST A-ASTC EAGER Project: STEM Education Practitioner Resource}

\begin{tabular}{|c|c|c|c|}
\hline $\begin{array}{l}\text { 영 } \\
\text { 일 }\end{array}$ & \multicolumn{3}{|c|}{$\begin{array}{l}\text { To address current challenges and reform efforts in STEM education, there is a need to build a unified } \\
\text { community of STEM education practitioners who are informed of current research and understonding in the } \\
\text { field. }\end{array}$} \\
\hline & $\begin{array}{l}\text { EM Education Practitioners: } \\
\text { 1. Educators in formal, classroom settings } \\
\text { 2. Educators in informal, out-of-school settings }\end{array}$ & 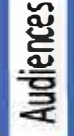 & $\begin{array}{l}\text { Resear chers i i STEM education } \\
\text { and the Learning Sciences }\end{array}$ \\
\hline 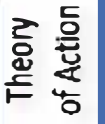 & \multicolumn{3}{|c|}{$\begin{array}{l}\text { In order to develop a community of STEM education practitioners, there is a need for a resource that connects } \\
\text { STEM education practitioners across settings while als o providing updates regarding the rapidly growing } \\
\text { research and knowledge base in STEM education. }\end{array}$} \\
\hline & $\begin{array}{l}\text { lase 1: Research Development/Market Needs } \\
\text { sessment } \\
\text { - Conduct a landscape assessment to } \\
\text { inventory current print and electronic } \\
\text { resources to identify gaps in the } \\
\text { availability of resources; } \\
\text { - Identify wrget audiences from related } \\
\text { professional organizations (eg., NSTA, } \\
\text { ASTC, AZA, ACM, NARST, AERA); } \\
\text { - Implement a national survey and conduct } \\
\text { focus group discussions to seek input } \\
\text { from target audiences (both formal and } \\
\text { informal/outof school educators). }\end{array}$ & & $\begin{array}{l}\text { Phase 2: Information Dissemination } \\
\text { - Develop, implement, and evaluate } \\
\text { two pilot issues of the STEM } \\
\text { education resource; } \\
\text { - Measure the target audiences' } \\
\text { engagement and interest with the } \\
\text { content of the pilot issues; } \\
\text { - Seek formative feedback from torget } \\
\text { audiences related to the pilot issues } \\
\text { to reiteratively develop and refine the } \\
\text { resource. }\end{array}$ \\
\hline $\begin{array}{l}\bullet \\
\bullet\end{array}$ & $\begin{array}{l}\text { Outcomes } \\
\text { Increased awareness and understanding of } \\
\text { research findings and the knowledge base in the } \\
\text { STEM education field by practitioners; } \\
\text { Increased dialogue and collaboration between } \\
\text { formal and informal/out-of-school STEM } \\
\text { educators; }\end{array}$ & & $\begin{array}{l}\text { Impact on the STEM Education Field } \\
\text { A sustainable resource that features STEM } \\
\text { education research as well as innovative curricula } \\
\text { and programs; } \\
\text { A cycle of research informing practice and } \\
\text { practice informing research in the STEM } \\
\text { education field. }\end{array}$ \\
\hline
\end{tabular}




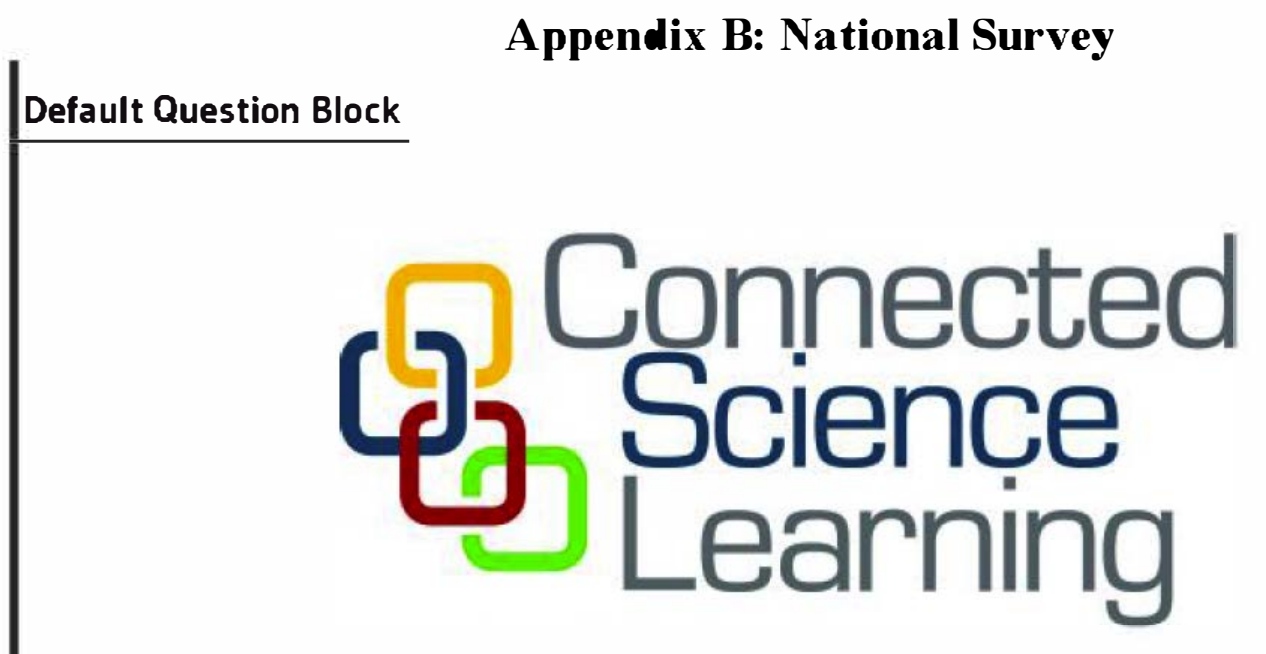

Thank you for accessing the survey to share your input and perspectives on the NSF-funded journal project, Connected Science Learning: Linking In-School and Out-of-School STEM Learning.

Connected Science Learning (CSL) is a collaborative initiative between the National Science Teachers Association (NSTA) and the Association of Science-Technology Centers (ASTC).

This survey is designed to help us better understand potential outcomes of the CSL journal and to gather feedback to inform the iterative development of the journal. The survey should take approximately 15 minutes to complete and your participation is voluntary. If you have any questions, please contact Kelly Riedinger (kelly.riedinger@oreaonstate.edu).

Thank you for your participation!

Prior to receiving this survey, were you aware of the Connected Science Learning: Linking In-School and Out-of-School STEM Learning journal?

Yes
No
I'm not sure

How did you learn about the Connected Science Learning journal? (Please select all that apply.)

\begin{tabular}{ll}
\hline$\square$ NSTA website & $\square$ ASTC's journal, Dimensions \\
$\square$ NSTA e-newsletter & $\square$ From a colleague \\
In another NSTA journal (e.g., Science and & $\square$ Online discussion forum or group \\
Children, Science Scope) & $\square$ Social media (Facebook, Twitter) \\
$\square$ ASTC website & $\square$ At a professional conference \\
$\square$ Informer (ASTC's bi-weekly email news &
\end{tabular}


bulletin)

$\neg$ From CSL journal project team/staff

From an CSL author/contributor

Through participation in a focus group or survey

$\bigcirc$ Other (please specify):

Are you subscribed to receive the online Connected Science Learning journal and related announcements and updates?

Yes

No

I'm not sure

Through which organization did you subscribe?

NSTA

ASTC

Both NSTA \& ASTC

I'm not sure

Other (please specify):

$\square$

If you have not yet subscribed, why not? (Please select all that apply.)

I was not aware that I could subscribe

I do not know how to subscribe

I do not want to receive the journal and updates to my email

Other (please specify):

$\square$

To date, how would you describe your engagement with the Connected Science Learning journal? (Please select all that apply.)

$\square$ I read through the entire first issue

$\square$ I read through the entire second issue

I have read through some of the articles from the first issue

I have read through some of the articles from the second issue 
I have explored the Connected Science Learning website but have not yet read any of the articles

I am aware of Connected Science Learning but I have not yet looked at the website or journal

Other (please specify):

How often do you visit the Connected Science Learning website?

Frequently (about once a day)

Often (about once a week)

Occasionally (about once a month)

Rarely (just a few times a year)

Never

Overall, how satisfied are you with the Connected Science Learning journal? Please use a scale from 1-10 where "1" is "not at all satisfied" and "10" is "very satisfied."

1. Not at

all satisfied

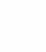

2

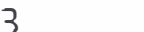

○

$\bigcirc \quad 0$

How likely are you to continue following the Connected Science Learning journal as new articles and issues are released? Please use a scale from 1-10 where "1" is "not at all likely" and "10" is "very likely."

1. Not at

all likely

3

4

5

6

7

10 - Very

$\bigcirc$

0

0

$\bigcirc$

8

9 likely

How likely are you to recommend the Connected Science Learning journal to a colleague? Please use a scale from 1-10 where " 1 " is "not at all likely" and "10" is "very likely."

1 - Not at all likely

3

4

5

6

7

8 10 - Very 9 likely

Please elaborate on your ratings: 


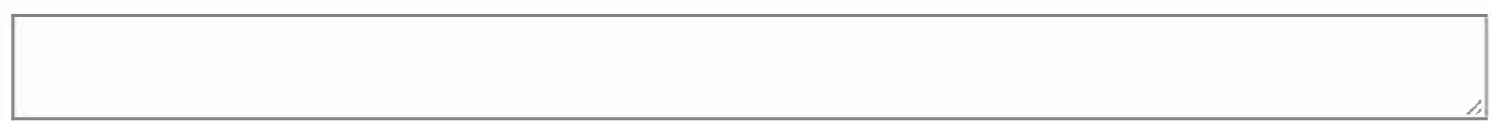

How would you describe the Connected Science Learning journal to your colleagues?

In the first issue of Connected Science Learning, the articles were released at the same time. The second issue was serialized, with articles released over a three-month period. Which method of the journal's release do you prefer?

I prefer that the articles are released at the same time

I prefer serialization with articles released over time

I do not have a preference either way

What do you see as the potential trade-offs of each approach?

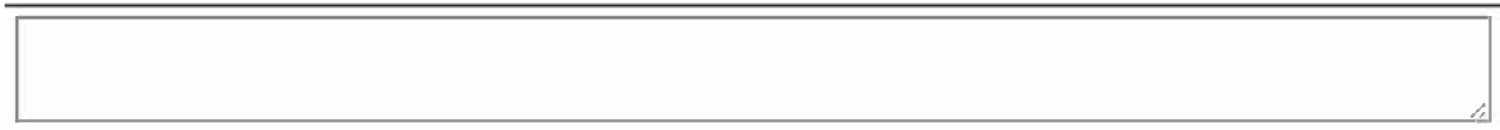

Please indicate your level of agreement with the following statements:

\begin{tabular}{l|ccc}
\hline & $\begin{array}{c}\text { Strongly } \\
\text { Agree }\end{array}$ & $\begin{array}{c}\text { Neither } \\
\text { Agree nor } \\
\text { Disagree }\end{array}$ & $\begin{array}{c}\text { Strongly } \\
\text { Disagree }\end{array}$ \\
\hline $\begin{array}{l}\text { As a result of Connected } \\
\text { Science Leaming, I learned } \\
\text { about research in the STEM } \\
\text { education field }\end{array}$ & & & \\
As a result of Connected & & & \\
Science Leaming, I learned \\
more about other settings \\
for STEM learning
\end{tabular}

Is there anything else you have learned as a result of Connected Science Learning? Please explain: 


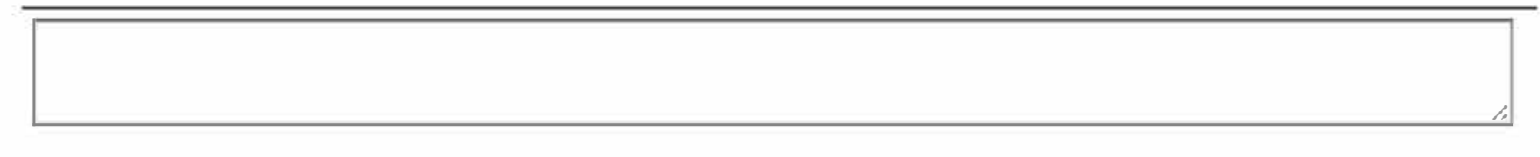

Please explain any ways (if at all) you plan to use information or ideas you learned as a result of Connected Science Learning:

In what ways, if any, have you connected with other STEM education professionals as a result of the Connected Science Learning journal? (Please select all that apply.)

$\checkmark$ I emailed an article author/contributor

I shared an article(s) with a colleague(s)

I have contacted other education settings for potential partnerships and/or collaborations

$\square$ I have developed a new partnership and/or collaboration

I have expanded my professional network

I have not yet connected with any other STEM education professionals

Other (please specify):

What do you think is Connected Science Learning's most important contribution or value to the STEM education field?

The journal offers practical applications of STEM education research

The journal fills a current gap in the field by featuring successful partnerships between inschool and out-of-school settings

The journal serves as a mechanism for connecting STEM education professionals across settings

The journal provides out-of-school education practitioners a space to write about and share their work

Are there any other ways you feel Connected Science Learning contributes to the STEM education field? If so, please elaborate: 
If the Connected Science Learning journal was offered only through subscription, how much would you be willing to pay annually to access the journal? Please use the slider below to indicate

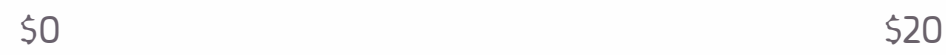

$\begin{array}{lllllllllll}0 & 2 & 4 & 6 & 8 & 10 & 12 & 14 & 16 & 18 & 20\end{array}$

I would be willing to pay annually (in dollars):

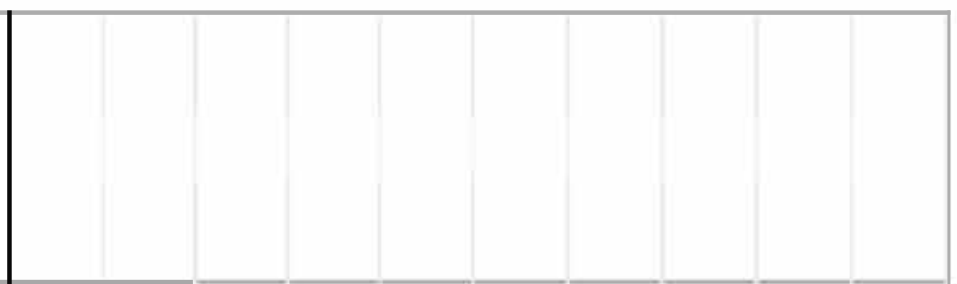

If Connected Science Learning were to be offered as an open-acces journal, but requested a donation (similar to Kickstarter or Wikipedia), would you be willing to contribute?

Yes

Maybe

No

What other themes or topics would you like to see explored in future issues of Connected Science Learning?

How would you describe your current professional position? (Please select all that apply.)

\footnotetext{
Prek-12 classroom teacher

District science coordinator

Member of the media (e.g., public broadcast, newspaper, radio, $T V$, podcast, internet)

$\square$ School or district administrator

$\square$ College/university faculty member

$\square$ Instructional coach or professional development specialist

$\square$ College/university staff

$\square$ Curriculum developer

$\square$ College/university student

$\square$ School assessment specialist

Scientist or engineer

Educator at a museum or museum-like setting (e.g.,

science center, planetarium, historic house or site)

Educator at a zoo, aquarium, or park (e.g., botanical garden, arboretum, national park, wildlife center)

$\square$ Govemment agency employee engaged in education

$\square$ Business/industry professional in education

Independent consultant (e.g., evaluation consultant)

Community or program educator (e.g., afterschool, camp,

$\square$ scouts, $4 \mathrm{H}$, environmental or nature centel, field station or $\square$ Other (please specify): marine lab)
} 
From the following list, please indicate the professional organization or group you are most involved or engaged with:

\footnotetext{
National Science Teachers Association (NSTA)

Association of Science-Tech nology Centers (ASTC)

CNARST

CAmerican Educational Research Association (AERA)

CThe Association for Science Teacher Education (ASTE)

National Science Education Leadership Association (NSELA)

Association of Zoos and Aquariums (AZA)

Afterschool Alliance

National Marine Educators Association (NMEA)
}

Citizen Science Association (CSA)

North American Association for Environmental Education (NAAEE)

National Association of Biology Teachers (NABT)

American Association of Physics Teachers (AAPT)

C National Earth Science Teachers Association (NESTA)

American Association for the Advancement of Science (AAAS)

American Society for Engineering Education (ASEE)

International Technology and Engineering Educators Association (ITEEA)

Other (please specify):

How many years have you been involved as a professional in the STEM education field?
$0-2$ years
3-5 years
6-10 years
$11-15$ years
$16-20$ years
More than 20 years

What is the highest level of education you have completed?

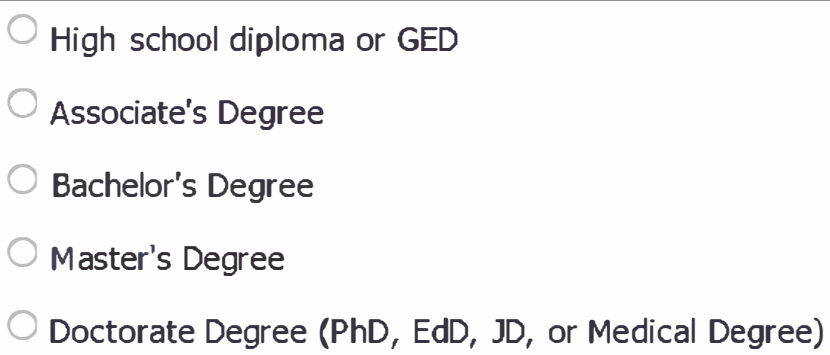

Do you have any final thoughts or comments you would like to share regarding Connectied Science Learning? 


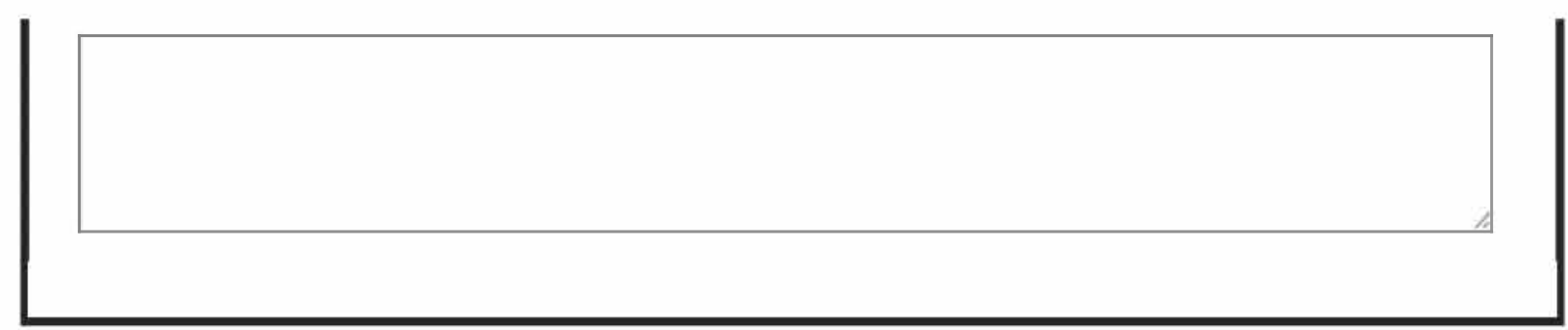




\title{
Appendix C: Focus Group Guide
}

\author{
Connected Science Learning: Linking In-School and Out-of-School STEM Learning
}

Summative Study: Focus Group Discussion Guide

\section{Focus Group Discussion Guide}

1. Briefly ask for a show of hands for the following:

- First, by show of hands, how many of you were aware of the Connected Science Learning journal before being invited to this focus group? (Record responses)

- How many of you read the first, inaugural issue of the journal launched in March of this year? (Record responses)

2. What do you think is the potential value of the Connected Science Learning journal for the science education field?

3. Has engaging with the Connected Science Learning journal influenced your thinking about science teaching and learning?

a. Why or why not?

b. Can you share an example or anecdote of how it has influenced your thinking?

4. In what ways, if at all, has the Connected Science Learning journal made you more aware of research in the science education field?

5. Has the Connected Science Learning journal helped you connect with other educators? If so, please describe or share an example.

- To what extent do you think that the Connected Science Learning journal could serve as a mechanism for connecting educators across settings?

- Do you have any specific recommendations or strategies for using the journal as a mechanism for connecting educators across a broad range of education settings?

6. The second issue of the journal will be "serialized" - This issue will take advantage of the web-based platform and NSTA/ASTC will release segments of the issue over three-months. Subscribers of the journal will receive an email each month notifying them of the release of new articles.

- What are the potential trade-offs of this approach?

- What suggestions do you have for maximizing the benefits of this approach while minimizing any potential disadvantages? 
Summative Study: Focus Group Discussion Guide

7. What other suggestions or recommendations would you like to share for improving the Connected Science Learning journal and related website?

8. Are there any other final ideas or comments you wish to share? 